\title{
SOME NOTES ON TWO EARLY ROMANCES-HUON DE BORDEAUX AND MELUSINE ${ }^{2}$
}

\section{BY F. W. BOURDILLON}

$T$ T has long been common knowledge among bibliographers that there is an edition of Huon de Bordeaux bearing 1 a date three years earlier than that mentioned as the first edition by Brunet; but the relation of this edition of I 513 to that of I5I6 has not, as far as I know, been hitherto described. A brief account of these two editions, with a classification of all editions, may therefore be acceptable to members of the Bibliographical Society.

The two editions of 1513 and 1516 are for all ordinary purposes one and the same book; and a copy of either which had lost both title-page and colophon would require the closest scrutiny to decide to which edition it belonged. The type is the same; the woodcuts (with a single exception) the same; the page-wording and the placing of the cuts is throughout the same. In fact, it is evident that for the greater part of the book there was only one setting of the type. The points of difference are the following :

1. The title-page and the colophon.

(1513) LEs prouesses et faitz mer-/ueilleux du noble Huon de bordeaulx per de france, duc/de guyenne. Nouuellemēt redige en bon francoys \& im/prime par le congie et preuilege du Roy nostre sire cōme/il appert a la fin de la table de ce present liure.

[Below : woodcut of the Plumed Horseman.]

(f. clxxxviii recto :) I Cy finissent les faictz et gestes/du noble Huon de bordeaulx duc de/guyenne \& per de france./

1 Part of a paper read before the Bibliographical Society, December Igrg. 
Auecques/plusieurs aultres faitz \& prouesses/daulcuns Princes regnans en son/temps. Nouuellemēt imprime a pa/ris par Michel le noir Libraire iure/en luniuersite de paris. Demourās/en la grant rue sainct Jacques. Le-/quel a preuillegc du Roy nostre sire/que nul autre que luy ne le peult $\mathrm{im} / \mathrm{primer}$ ne faire imprimer autre que/luy et ses commys iusques a deux/ans finitz \& acomplys a prendre du/ior que ledict liure sera imprime qui/est le .xxvi. iour de nouembre mil. $\mathrm{v} /$ cens et treize.

[Below : M. le Noir's device.]

(I516) LEs prouesses et faictz mer-/ueilleux du noble Huon de bordeaulx per de france, duc de guy-/enne. Nouuellement redige en bon francoys et imprime par le/ congie et preuilege du Roy nostre sire.

[Below : woodcut of the Plumed Horseman.]

(f. cloxxviii.) đ Cy finissēt les faictz et gestes du/noble Huon de bordeaulx duc de guy/enne et per de france. Auecques plu-/sieurs aultres faictz \& prouesses daul/cuns Princes regnans en son temps/Nouellement imprime a Paris le./xxiiii. iour de decēbre. Mil cinq cens/et seize. Pour Jehan Petit Libraire/Jure en Luniuersite de Paris. De/mourāt en la grāt rue sainct Jaques.' I Cum Preuillegio.

[Below : Petit's device.]

2. In 1513, the Table of Contents at the beginning is followed (sign. $\bar{a}$ [vi] verso) by the 'preuilege', which occupics the whole page.

In 1516 , the 'preuilege' does not appear; but its place is filled by a large woodcut of a bare-headed man on his knees prcsenting a volume to a king enthroned and crowned. This cut is found in other books of Michel and Philippe le Noir, e.g. the Jardin de Plaisance, s.d., and the Illustrations de Gaulle, I524.

1 This is according to the copy before me. In Brunet the words that follow the date are given as: par Michel le Noir. 
3. In the rest of the book some fifteen leaves show perceptible points of difference. Even, however, where a page or a leaf carries some salient and unmistakable sign of new setting, as in words abbreviated or written in full, the general appearance of the page is most deceptively similar, and it is quite possible that other leaves than the fifteen I have observed may have been reset, reset to the point of facsimile. In a considerable number of cases, however, a lifted spaceblock, or a worn letter, or a marked irregularity of line offers sure evidence of the page being of the same impression.

All copies I have seen of the earlier of these two editions bear the name of Michel le Noir ; but in the 1516 edition the name of his close ally and frequent coadjutor Jehan Petit ippears in some copies instead of his own. This second dition was not issued till a full year after the expiration of tie previous 'Privilège'; nor would it seem that any rival eition was even then threatening, as the next extant edition is the quarto issued by the widow of Jehan Trepperel, and mit have appeared between 1522 and 1527 -that is, at least six rears later. I regret that $I$ have not seen a copy of this editon, and cannot therefore give any account of it, or say whairelation it bears in text or illustrations to Le Noir's.

Thase two Le Noir editions-for I think there is sufficient differnce to justify the use of the often-abused word edition : to cal them merely two issues would be rather misleading, in vie of the reprinting of at least seventeen leaves and possibl; more, and further in the absence of the Privilège in the secnd-these two editions are illustrated throughout with wodcuts altogether identical except for the additional cut takir the place of the Privilège, which makes the number in the sennd 88 instead of 87 . There are only 14 repeats, so that thercare respectively 73 and 74 separate cuts. Of these, twenty cerainly, and perhaps one or two more, are special cuts desigrd for this work; and these are regrettably bad: 
not the worst of the worst, such as the shameless atrocities found in the cheaper and later Paris Romances, but very decidedly poor work, inferior though conscientious in design, and correspondingly inferior in cutting. Yet of six of these -poor things transfer-copies even worse appear in Denys Janot's later undated edition of the same Romance.

The cut on the title-page is the handsome and well-known cut of a Plumed Horseman. This fine cut appears in several of Le Noir's books, and this is not its first service; for it had been used eleven years before in the edition of Beuves d'Anthonne (Bevis of Hampton) published by Le Noir in I502: I do not know of any earlier appearance.

The remaining illustrations are for the most part small cuts familiar in Le Noir's publications. They evidently belong to several different series, and all probably began life a illustrations to some particular work, to which it may som: day be possible to trace them. But besides the smaller ci:s there are six of larger size and more interesting. Thsc six cuts (eleven with repeats) belong to the famous seies illustrating the Destruction de Troye le Grand of Jacrues Millet (a sort of Mystery-play in verse, founded on Coloma's Troy book), which was published at Paris by Jacques Jonhomme in 1484. Of this Troy book M. Claudin says 'It ' is one of the earliest and most remarkable books printer with ' woodcuts at Paris, the illustrations designed by a realirtist, " who has given a true character of life and movementio the 'persons represented.' Mr. Pollard, in the Pierpont Jorgan Catalogue, agrees in this appreciation of these cuts, though he thinks that more than one artist and several cuttrs wcre employed on them. There were three editions of ais work issued at Paris in the fifteenth century, the second nd third being published by Vérard, into whose hands the bicks seem to have passed. After the edition of 1498 the $\mathrm{cl}^{\mathrm{S}}$ are not found again as a set, so far as I know. Whether sore of them 
perished with Vérard's shop on the bridge that fell the next year we cannot tell; but of the complete set of 27 cuts about half are found promiscuously in books of a later date, and at least eleven of them appear after the death of Vérard to have come into the possession or control of Le Noir, as they occur fairly frequently in books bearing his name.

The I 5 I 3 edition of Huon de Bordeaux is the earliest known, and is always presumed to have been the first printed. It may be pointed out, however, that the colophon states it to be 'nouvellement imprimé', words which usually imply a previous edition; and further that 1513 is a late date for the first appearance in print of such an important Romance; most of the other chief favourites, such as Ogier le Danois and the Quatre Filz Aymon, had been many years in print by this time, either at Paris or Lyons or both ; and lastly, friend Michel le Noir was a publisher who followed rather than led, and almost all his publications were books which had already been successful with other publishers such as Vérard or Trepperel. So much has been lost--so many early books exist only in single copies-that it seems more probable than improbable that there was an editio princeps, now lost, of Huon de Bordeaux.

Following these two editions of Le Noir come several without date, which can only be arranged and dated conjecturally, according to the time in which their various publishers are known or supposed to have been in business.

Of these, the first in order is probably that published by the widow of Jehan Trepperel, whose name appears alone in books between 1522 and $15270^{1}$ I have not seen this edition, of which there is no copy in the British Museum. The title and colophon are given in Brunet, and need not be reproduced here.

The undated editions of Olivier Arnoullet at Lyons and

${ }^{1}$ Harrisse, Excerpta Columb. Introd. p. xlviii. 
Denys Janot at Paris may be provisionally arranged in this order, as the former published a book as early as $1525 .{ }^{1}$ while according to Renouard, Denys Janot is only found at the address given in his Huon de Bordeaux after 1532. This latter is not mentioned in Brunet, but there is a copy in

the British Museum. The colophon runs as follows :
'Cy finissent les faictz et gestes du noble Huon de Bor-s - deaulx Duc de Guyenne et Per de France. Auecques: ' plusieurs aultres faictz et Prouesses daulcuns princes regnans ' en son temps. Nouellement imprime a Paris par Deny's ' Janot demourant en la rue neufue nostre Dame a Lymaigc ' sainct Jehan Baptiste pres saincte Geneuiefue des Ardans.'

The woodcuts are all but one transfer-cuttings from those in the edition of 1513 . There appear to be some ten or twelve, including two repeated. But eight pages are missing in theo British Museum copy (signatures i and k).

The edition of Jean Bonfons, who published from 1547 to 1568 , is almost certainly later than the two last-named. Both on the title-page and in the colophon it is stated that $\mathrm{it}^{\mathrm{ta}}$ is 'Imprime nouuellement pour Jean Bonfons, Librairc 'demourant en la Rue neuıue nostre Dame a lenseigne sainct 'Nicolas'; but no date is given. The book contains nince woodcuts (with repeats, fourteen), old cuts re-used, ando without any special merit or interest except that on the title-page. This, however, is a superior cut, representing a king riding in procession under a canopy; it is from the

1 Galien Retbore. Brunet notes that the copy he had seen had lost its: colophon, so he gives no date. But Vingtrinier, Histoirc de l'imprimerie a Lyor:, 1894 , p. 187, gives the date as above. He mentions also a book published by one or other of the Arnoullets, he does not say which, with an earlicr date still : Les Gestes des Tbolosains, 1517; this book was apparently unknown ton Brunet.

8 In the British Museum catalogue this book is dated thus $I\left[56_{5}\right]$. the figures $\mathrm{lxv}$ on the title-page (denoting the number of cabiers) having, as often. been talen for the date. 
original block, and not from the transfer-cutting which appears in other books. In Three Hundred Notable Books,' p. 77, a facsimile is given of this cut from Petrarch's Triomphes, I520, its first recorded use apparently. But the fleur-de-lis decoration on the canopy and the general design suggest that the cut was originally used (or intended) to represent some actual occasion; for instance, the coronation or entry into Paris of Francis I, for whom the youthful king on horseback might very well be meant. Of the other cuts, two are poor transfer-cuts of Le Noir's Huon de Bordeaux designs mentioned on p. 23 above. We may note that the book contains 264 leaves, but the cuts all occur in the first third of the volume, there being no more illustrations after fol. lxxii.

After these we come to a few editions which bear dates, the first of which is an octavo of 1566 of which Brunet can record nothing except that it is mentioned by $\mathrm{Du}$ Verdier. He had not seen the book himself, neither have I.

The quarto published at Lyons by Benoist Rigaud, and dated I 586, has more to say for itself, and is an interesting book. It is well printed in Roman letter, and contains 360 pages numbered in arabic figures, with a final unnumbered leaf on which is nothing but a woodcut. The text of the romance in this edition has been a good deal altered and the sentences often pared down; and now for the first time (to my knowledge) the lengthy romance is divided into two parts or 'books', the division being made where there is no real break, but actually in the middle of a conversation, and in the middle of a chapter, into which a new chapter-heading is inserted. ${ }^{2}$ Although the whole is paged continuously, the second 'book' begins at a second set of signatures, the first being $A-Z$, the second $A A-K K$. In fact it looks very much

1 ' Three Hundred Notable Books added to the Library of the British Museum under the keepership of Richard Garnett, 1899 .'

2 Cap. 106, though the chapters are not numbered in any of the early editions. 
as if the division had been determined in the printing office, and according to the convenience of the printer rather than consideration of the matter.

The book contains forty-five different woodcuts of all sorts and sizes, fifty-three with the repeats. None of these appear to be new nor, with a single exception, p. 297 (mist numbered 299), originally designed for this romance. But their very variety gives them some interest, as they forra almost a connected exhibition of Lyons woodcuts from this rude beginnings learned from Basle (p. 253) down throug the promising second stage when the Lyons woodcutter had begun a style of their own (PP. 120, 124, 270, \&c.) to this later period when the influence of Venetian cuts had swampeg this hopeful beginning with mediocre imitations of the Italian style and copies of Venetian designs. Thus on p. $27 \%$ there is a reduced copy of one of the three-compartmenteg: cuts to Ovid's Heroides, Venice, Tacuino, I 501 (Hero ant Leander), and on p. I9 a miniature cut derived (througf a previous reduction in Boulle's Lyons edition of 1527) from Ovid's Metamorphoses, Venice, I 497 (Bk. viii, Nisus ancै Scylla). On the title-page is a cut of a knight on horseback with vizor raised, both horse and man staring fixedly a a a shield hung on a tree, which shield bears the monogram of $\mathrm{BR}$, i. e. Benoist Rigaud, the publisher of the book. On the last leaf is the cut of a man on horseback, the horse wearin a plume and half turned to the spectator, which is used of imitated on the title-page of the succeeding small octar editions of Lyons and Rouen.

There were six of these, three from Lyons and three fror Rouen. The Lyons are dated $1606,1612,1626$; of the Rouen none has a date. I have not seen the edition which appears to have set the style, that of 1606 ; but therc is copy of the next, 1612, in the British Museum (misdated in the catalogue 1611 ), and from this it is evident that the Rouen 
three imitated closely the Lyons three in 'format', type, and illustrations. In all, the illustrations are few and mostly of second-rate quality. The subjects are so vague and general that it is impossible to say if any of them were designed specially for their present purpose. They fit the page very well. The Rouen editions seem the most common, and occur fairly often, sometimes in one volume and sometimes in two.

The Romance after this seems to have fallen quite out of favour, like the rest of its kin, and there is a long gap, till we come to its revival in the chap-books of Troyes, Lille, and Rouen. The earliest of these that $I$ have seen is that of Troyes with the date 1705; and there were many succeeding. Every one knows these Troyes chap-books, and I need not describe them. But there is one very significant alteration of the text which marks the boundary-line separating the chap-book stage completely from the earlier editions. This is in the later part of the Romance, in one of the additions to the original story called Ide and Olive. The heroine Ide, dressed as a man, has done great deeds of prowess on behalf of the Emperor of Rome, whose daughter Olive of course falls in love with the victorious hero; there follows the discovery of her sex, and she is condemned to be burned. The next chapter-heading runs as follows: ' Comment nostre Sire feist 'grans miracles pour Yde, car il la fist estre homme, dont ' l'Empereur et Olive eurent grant joye.' With a great odour of incense an angel arrives and announces this miracle, and all goes merry as a marriage bell. But by the year 1700 the angel as Deus ex machina had lost his reality, and the miracle its credibility. In the chap-book version the original female Ide is left to be burned while Olive marries a prince of the same name, 'a fin de ne point corrompre cette histoire.' Could banality descend to a lower depth, or poverty of invention go more naked and unashamed? 
Huon de Bordeaux, early editions.

(* Only known through Brunet's account. † Not in Brunet.)

† 1. Paris, M. le Noir : 26 November 1513: fol.

2. Paris, M. le Noir : 24 December 1516 : fol. (sometimes with Jehan Petit's name instead).

3. Paris, Jehan Trepperel, s.d. : 4to.

† 4. Paris, Denys Janot, s.d. : 4to.

* 5. Lyons, Olivier Arnoullet, s.d. : 4to.

6. Paris, Jehan Bonfons, s.d. : 4 to.

* 7. Paris (no information), 1566:8vo.

8. Lyons, Benoist Rigaud, $1586: 4$ to.

* 9. Lyons (no information), $1606: 8 \mathrm{vo}$.

Io. Lyons, Pierre Rigaud, I612 : sm. 8vo.

$\dagger$ I I. Rouen, Louys Costé, s.d. : sm. 8vo.

I2. Rouen, Veufue L. Costé, s.d. : sm. 8vo.

* I3. Lyons, J. Huguetant, I626: sm. 8vo.

Chap-book editions.

Troyes, Jacques Oudot, 1705: 4 to.

Do. do. 1707 (priv. 1705): 4to.

Do. do. (approbation to his widow, $26 \mathrm{Mla}$ 1723): 4to.

Do. Veuve Oudot \& Jean Oudot fils (permission confirme July I725): 4 to.

Do. as the last, but second part dated on title-page $172 \mathrm{~F}$

(There are at least two different settings up of the type i editions with permissions of the same date.)

Troyes, Pierre Garnier, permission $1726:$ 4to.

Lille, Veuve Pillot, permission without name of publishcr $1726: 4$ to.

Rouen, Lecrêne-Labbey, s.d. (circa 1800) : 8vo. 


\section{MELUSINE}

Any bibliography of the Romance of Melusine must perforce take account of its literary history, because of the different versions of the different printed editions. These, however, all derive from the lengthy but interesting compilation of Jean d'Arras; and therefore for bibliographical purposes it is not necessary to go behind that, or attempt to analyse the various elements out of which this writer compounded his 'History'. To students of folklore and romance such an analysis presents very great interest, as well as to genealogists occupying themselves in the attempt to disentangle fact from fiction in the history of the House of Lusignan. Some effort at such disentanglement was made as long ago as 1587 by a member of that House ${ }^{1}$; but beyond its bibliographical interest the book has little claim to attention. The most recent work dealing with the subject is that of Jules Baudot, Les Princesses Yolande et les Ducs de Bar . . premiere partie, Mélusine, $8 \mathrm{vo}$, Paris, Igoo.

The Romance exists in three different forms; but these are not separate and distinct versions of the story, the second being derived directly from the first, the third directly from the second.

I. Melusine : Romance in prose compiled by Jean d'Arras, $1387-93$.

a. Exists in several manuscripts, one in the British Museum (Harley 4418).

b. Printed by Steinschaber at Geneva, 1478 .

c. Edited from this edition by $\mathrm{Ch}$. Brunet in the Bibl. Elzév., 1854.

d. Englished about 1500 . Unique manuscript in British Museum : Royal I 8 B, ii.

1 Les genealogies de soixante et sept très-nobles et très-illustres maisons . . . par R. P. Estienne de Cypre, de la Royale Maison de Lusignan : 4to, Paris, G. Lenoir, 1587 . 
32 . Some Notes on Two Early Romances

e. Edited from this manuscript by A. K. Donald, Early English Text Society, 1895 .

f. English version condensed and modernized in John Ashton's Romances of Chivalry, London, $1887 .^{1}$

2. The Roman de Partbenay, or Roman de Lusignan, an abridgement and partial rearrangement of Jean d'Arraso Romance in verse by a poet named Coudrette (or Coudrecte)

a. Exists in a good many manuscripts, one in the Britisl Museum : Add. 6796.

b. Edited by Francisque Michel, Niort, I 854 .

c. Englished about 1500-1520. Unique manuscript it Trinity College, Cambridge.

d. Edited from this manuscript by W. W. Skeat, Earlog English Text Society, 1866.

3. Melusina, German prose version rendered from Cou drette's poem.

a. Exists in manuscripts. (See Schorbach, Zeitscbrif虚 für Bücberfreunde, i. 138.)

b. First printed by Bamler, Augsburg, 1474 (copy i i British Museum, G 19934). Very numerous sub? sequent editions.

c. A fairly close English version from a modern Germa edition by Mrs. Leighton in Mediaeval Legends London, $\mathbf{I} 895$.

The existence of a second and derivatory form of thễ romance must be put down to two causes : firstly, to the pro lixity of the original compilation, and secondly to the unskilfu and ill-balanced plan of it. Jean d'Arras, excellent as he in description and narrative, shows himself anything but

1 For bibliographical purposes account must also be talen of 'Geoffroy à $\sqrt{3}$ grand dent', a portion of the prose romance of Jean d'Arras, first printed be Olivier Arnoullet, Lyons, 1549 . There is a modern French version by Alfred Delvau in the Nouselle Bibliotbegue Bleue, vol. iii, p. 289 , as well as a version of Melusine in modern French. 
skilful in the construction of a long story, or the management of a drama complicated by many details and side-shows. Possibly, too, he was hampered by instructions from his patron and the necessity of glorifying the House of Lusignan. The result is that the comparatively simple and engrossing story of Melusine is interrupted by an immense interpolation relating at full length the deeds of four of her sons, how they conquered great kingdoms and gained wealthy wives. The Romance, indeed, might be divided into four parts : the first telling the early history of Raymond and Melusine; the second, the feats of the four sons above mentioned; the third, the continuation of the story of Melusine proper; and the last, the adventures of Geoffrey of the Great Tooth.

It is not surprising to find that a later lord of the House of Lusignan commissioned a professional poet to rewrite the Romance; and in the poem of Couldrette the inconveniences and misproportions of the prose romance have been skilfully rectified by an evidently practised hand. The whole has been reduced to about one-third of its original length; the unwieldy interruption has been cut down to a few side episodes that are worked into the general plan of the story without undue distraction; and a judicious rearrangement in a few places has markedly improved the scheme of the story, and given it more cohesion and dramatic development.

But together with the considerable gain in briskness and sustained interest there is also a very perceptible loss in vividness and realistic quality. The original prose romance displays a somewhat remarkable power of graphic description and genuine character-drawing. The incidents of fight and foray suggest strongly that the writer had himself witnessed scenes of the kind; and the 'berserker' character of Geoffrey of the Great Tooth, who always swears ' by the tooth of God', is well sustained and 'convincing' enough for the work of a modern novelist. In the Court poet's smug octosyllabic 
couplets most of these qualities disappear or are softened down; and the interest of the story as mere story is brought out and made paramount. If we imagine Rob Roy cut down and condensed and retold in pretty drawing-room versification, we have a fairly adequate picture of the difference between the Melusine of Jean d'Arras and the Roman de Partbenay of Couldrette.

This disquisition on its literary history has been necessar to explain the bibliography of the Romance. The poem of Couldrette itself was not indeed printed in early days; bue it was this and not the original romance that was renderest in the German prose version which is the editio princeps or Melusine, and which won such popularity for the story i Germany that no fewer than thirty editions were printed in the course of the next hundred and fifty years. Further, it wac the early German editions that first illustrated the book with woodcuts; and, as so often happened in the case of romances and other books of the fifteenth and sixteenth centuries, the earliest illustrations set the mode for all succeeding, and these early German woodcuts were copied and imitated not onl in the German editions of the German version of Melusine but also in French editions of the French or original version And in this lies the explanation of a curious fact which mus? have struck every reader of the French prose romance ast reprinted in the Bibliotbeque Elzevirienne (the only accessible form of the original), namely, the extraordinary difference in length of the chapters as marked by the chapter-headings some occupying but a page or two, and others extending orc twenty, thirty, even sixty pages. The fact is that thes apparent chapter-headings were intended not so much fo 'arguments' of the sections into which they divide the work as for explanations of the illustrations to which they wcre attached. The first edition of the French or original text of Jean d'Arras, printed at Geneva, was illustrated with copies 
of the cuts in the earlier German edition, and the explanations of these cuts were translated into French and printed with the cuts in places to suit the French version, which as we saw is three times as long as the German. It followed naturally that there are very long passages in the French with no illustration and no picture-title, and therefore (in the unillustrated text) with no 'chapter-heading' or division of any kind. Had the modern text of the Bibliothèque Elzevirienne been taken from a manuscript instead of from the Genevan edition, the work would no doubt have shown a better system of divisions. The manuscript in the British Museum has but some six or eight illustrations, but is divided by chapterheadings into one hundred and sixteen chapters (as against sixty-five in the Genevan edition), according to the natural breaks or divisions of the subject-matter.

A full account and list of the German editions is easy of access in Schorbach's article in the Zeitschrift für Bücherfreunde, vol. i, P. 132 (June 1897). And Brunet mentions fourteen French editions, of which four are Incunabula. The first printed edition, containing the earliest series of woodcut illustrations, is by general agreement the German edition printed by Bamler at Augsburg and bearing the date I 74 , of which by great good fortune the British Museum possesses a very fine copy. The cuts in this are of early workmanship and design; but from them all succeeding are derived directly or indirectly. The next set of cuts appears in the German edition without place, date, or name of printer, which Schorbach and other authorities attribute to Bernhard Richel of Basle, and date between 1474 and 1478 . Schorbach asserts that these cuts are copied from the illustrations in a manuscript actually existing in the University Library at Basle. I live in hopes some day of testing this assertion for

1 This manuscript is slightly imperfect at the beginning, and possibly one or two miniatures and chapter-headings are missing.

c 2 
myself. Comparing these cuts with the Bamler, one would naturally assume that they were improved and enlarged reproductions of the earlier designs; just as the Husz and Le Roy cuts were intended to improve upon the Ortuin in the case of the Roman de la Rose. The first French edition is almost certainly later than this; and the cuts in it are copies, sometimes reversed, of its woodcuts. It was published not in France but at Geneva, and is dated 1478. M. Claudin waš certainly misled in supposing that the copying was the other way about: he only knew the Richel series from their after appearance in a Lyons edition of the French version, and imagined that they were of French workmanship.

All the early editions of Melusine are so extremely rare that it is impossible to find copies of more than one or two in the same library or collection; and hence the comparison and inquiry as to their relation to one another is very difficult The Netherlands series described in Sir Martin Conway' Woodcutters of the Netherlands was first printed in I49I, and may therefore be derived from one or other of these three earlier series; but from mere description it is impossible to say; and all editions containing these cuts appear to be out of reach except at the cost of such journeying as Sir Martirif. himself undertook for the purpose of his work above mentionedo

Leaving the other sets aside, there are a few particulars with regard to the Richel cuts which I think are of sufficien interest to place before the Bibliographical Society in a con nected way. Originating at Basle, as illustrations to the German version, the cuts seem almost immediately to have passed on to Lyons, and reappear in three editions of the French version of Melusine printed there. (The relations of the printers and publishers of Basle and Lyons were close irs early days.) These three editions are described by $M$. Claudirir in his third volume, all being of the utmost rarity. the first, printed by Ortuin and Schenk, only two copies, both 
imperfect, are known. The next was issued by Guillaume Le Roy, and of that also only two copies exist, one of which is in the Douce Collection in Bodley's. Of the third, printed by Mathieu Husz, M. Claudin mentions only one copy-that at Chantilly. I have examined both copies of the second of these rare editions-at the Arsénal and at the Bodleian; and I found that the full series of the Richel cuts is reproduced in the book, with the exception of a single cut in the middle, and of the four illustrations at the end which illustrated the four chapters not existing in the French version of the Romance, in which therefore these four cuts had no raison d'être.

Besides these three Lyons editions, there is an edition in Spanish in which most of these same cuts appear, together with a few traced-cuttings reversed, replacing the original blocks. A copy of this is in the British Museum. It was printed at Toulouse in 1489 ; and strange as it seems to find perishable and easily injured wood-blocks wandering to and fro in this manner, it appears pretty certainly to have been issued between the second and third of the three Lyons editions, the last of which M. Claudin places conjecturally about I494, five years later than the date in the Spanish book. This is confirmed by the appearance in the Lyons edition of a reduced copy of the scene of Riding under the Stars in place of the original cut which was still in place in the Toulouse edition.

In the Toulouse impression of these cuts there is an interesting little specimen of wood-cutting craft noticeable in one of the blocks. The cut is used twice ; in the first use the formidable tusk which always marks Geoffrey of the Big Tooth had evidently got broken off the wood-block, and does not appear, nor does the mark like a lion's claw on his brother Anthony's cheek. But when the same cut is used later there is the big tooth again, reinserted by some device of the woodcutter, though perceptibly different from that which had been broken; and the lion's claw mark also appears again. 
From these Richel cuts were copied the several series which illustrate succeeding German editions, such as those published by Knoblochtzer at Strasburg, which are in the British Museum, and the smaller and worse edition of Knobloch, in which the little cuts are almost despicably bad, although this wretched edition was priced at over a hundred pounds in a bookseller's catalogue not long before the war.

In Mr. John Ashton's Romances of Cbivalry are smallö̆ reproductions of sixteen of the Richel cuts. Both Müther: and Claudin give full-sized facsimiles of some few of them.

As was said above, the chapter-headings in the earliest German editions are really only picture-titles, describing not the contents of the coming chapter but the particular scene in it which the woodcut illustrates. Those in the Richel edition, and their accompanying illustrations, correspond almost exactly to those in the Bamler edition; and the illustrations appear to have been certainly founded upon those in the earlier book, with the ambitious improvements of a mores highly developed art. There is a slight difference in theo numbers in the two editions, the earlier, Bamler, containing seventy cuts with a few repeats among them, or sixty-s three separate cuts. Richel has sixty-seven cuts with no: repeats. ${ }^{2}$ This difference is partly accounted for by the Richel cutter cutting separate designs for cuts which were repeated in Bamler, which would naturally give the formere seven more than its exemplar. But on the other hand Bamler twice gives two cuts to a single picture-title where Richel: only has one, and also in two places he has a cut where Richcls for some reason has none. Owing to the rearrangement of

1 All existing copies of the Richel edition appear to be imperfect; but fromis a comparison of several the above number of cuts has been computed to bcu what a perfect copy should contain. The numbers given here for the Bamler edition are taken from the excellent copy in the British Museum, but Hain $(* 11064)$ mentions 2 difference in copies. 
the story in Couldrette's version, there are in the German printed editions two stories at the end which are not there in the French prose romance- one is the tale of Melior who kept the Castle of the Sparrow-hawk; the other, of Palatine (or Palestine) who guarded the treasure of her father Helmas. The illustrations to these, four in number, are naturally omitted in the French printed editions, although both stories are in fact merely amplifications of what in Jean d'Arras is told, very briefly, in the prefatory part of his romance. See Melusine, Bibl. Elzév., p. 24.

It is to be hoped that some day facsimile reproductions may be made of all the three earliest editions of Melusine, the German editions of Bamler and Richel, and the French of Steinschaber. The exact relations of one to the other could then be clearly defined. 